\title{
NOTE ON CLADONIA SPECIES (LICHENIZED ASCOMYCOTA) FROM ARDAHAN PROVINCE (TURKEY)
}

\author{
PiOTR OSYCZKA ${ }^{1}$, KenAN YAZICI $^{2}$, Ali Aslan $^{3}$ \\ ${ }^{1}$ Department of Polar Research and Documentation, \\ Institute of Botany, Jagiellonian University \\ Kopernika 27, 31-501 Kraków, Poland \\ e-mail: piotr.osyczka@uj.edu.pl \\ ${ }^{2}$ Biology Department, Faculty of Science and Arts \\ Karadeniz Technical University \\ 61080, Trabzon, Turkey \\ ${ }^{3}$ Biology Department, Kazım Karabekir Education Faculty, \\ Atatürk University, Erzurum, Turkey
}

(Received: March 11, 2010. Accepted: June 1, 2010)

\begin{abstract}
This paper is the first report on Cladonia species from Ardahan, a north-eastern province of Turkey. A circumpolar boreal-low arctic species, Cladonia acuminata, rarely reported from Asia, and the recently described Cladonia monomorpha are reported as new for Turkey. Their detailed descriptions and taxonomical remarks are provided. Localities of other ascertained Cladonia species in the province supplement the knowledge of their distribution patterns in the country. In addition, the typically corticolous/lignicolous species Vulpicida pinastri is mentioned as also growing on primary squamules and podetia of $C$. pyxidata.
\end{abstract}

KEY WORDS: lichens, Cladonia, biodiversity, geographical distribution.

\section{INTRODUCTION}

Knowledge of the occurrence of lichens in Turkey is still insufficient, and this concerns both rare and even common species. Just recently lichen biota has been successively investigated in individual Turkish provinces and new species are still being added to the national list of lichens. At present, lichenological studies are being carried out in Ardahan Province (Yazici et al. 2010a, b). This study focuses on several Cladonia species which were ascertained in this region. Two of them, $C$. acuminata and $C$. monomorpha, are reported for the first time from Turkey.

Ardahan is a province of the Eastern Anatolia Region in the far north-east of Turkey where the country borders with Georgia (Fig. 1). According to the flora of Turkey (Davis 1965), the province is located in the grid square A9. It is a high mountain region where the continental climate is dominant, with a mild effect from the Black Sea. In Ardahan, Göle, and Hanak districts the climate is characterized by hot dry summers and cold snowy winters (mean annual temperature $6^{\circ} \mathrm{C}$ ) and the mean annual rainfall is about 500-600 mm. In the collection area of Posof district, microclimatic conditions with moderately rainy winters and hot summers dominate (mean annual temperature $6.8^{\circ} \mathrm{C}$ ) and mean annual rainfall is about $600 \mathrm{~mm}$ (Akman 1999).

\section{MATERIALS AND METHODS}

Specimens were collected in 2008 and 2009 in Ardahan Province. The collection of Cladonia species originates from Ardahan, Göle, Hanak, and Posof districts and the localities are marked on the map - Figure 1. The materials

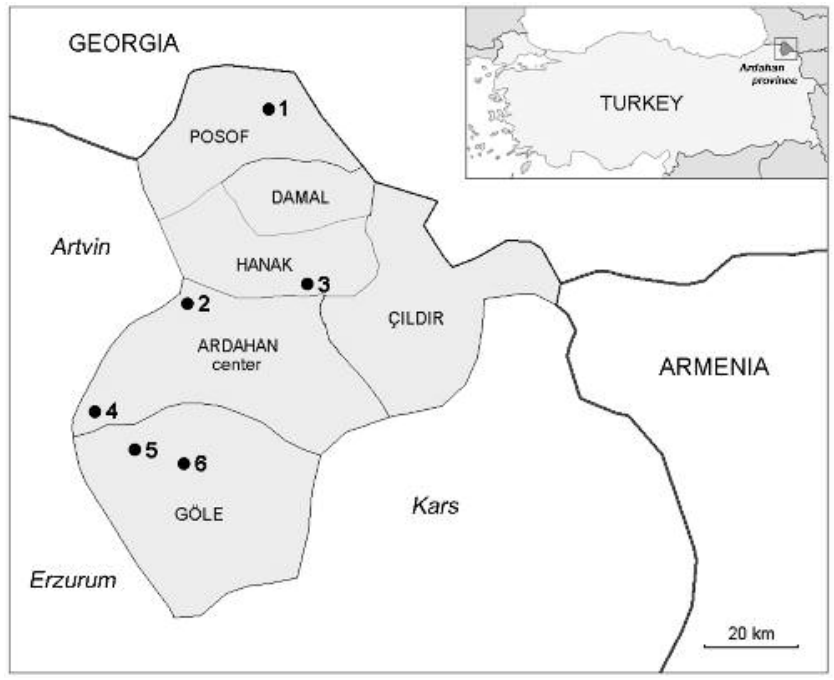

Fig. 1. Ardahan Province with localities of Cladonia under study. 


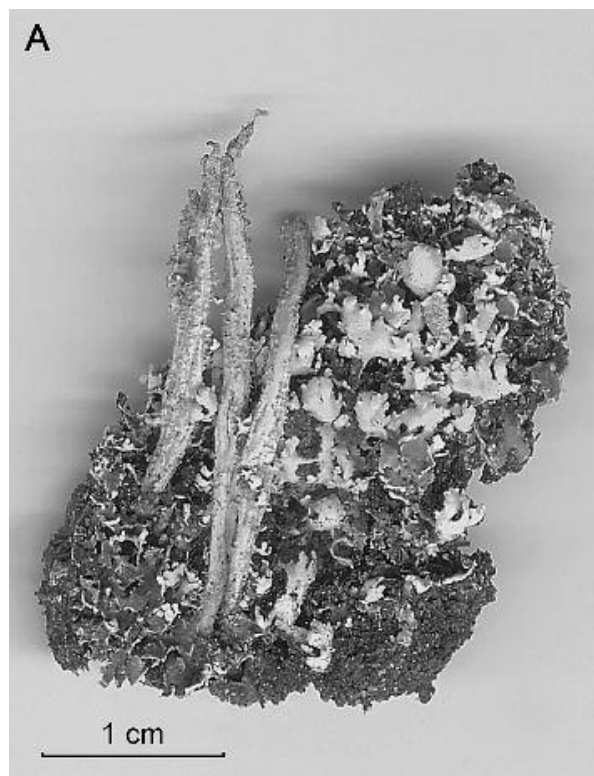

Fig. 2. Lichen specimens from Ardahan Province: A - Cladonia acuminata (Ach.) Norll., leg. K. Yazici, 07.12.2008 (KTUB 2024); B - Cladonia monomorpha Aptroot, Sipman \& van Herk, inside of cup, leg. K. Yazici, 12.04.2009 (KTUB 2025); C - Vulpicida pinastri (Scop.) J.-E. Mattsson \& M.J. Lai growing inside the cup of Cladonia pyxidata (L.) Hoffm., leg. K. Yazici, 12.04.2009 (KTUB 2028) were examined using standard microscopic techniques supported by chemical analysis. Lichen substances were determined by thin layer chromatography (TLC, in solvents A and C) using the standard methods summarized by Orange et al. (2001). Descriptions of the species are based on original collections. Voucher specimens are deposited in the Herbarium of Karadeniz Technical University, Biology Department, Trabzon, Turkey (KTUB).

\section{RESULTS AND DISCUSSION}

Ten species of the genus Cladonia were recognized in the material studied from Ardahan Province. The species reported as new for Turkey are characterized and discussed in details, other taxa are juxtaposed below with their localities in the region. Cladonia symphycarpa has been sporadically reported from Turkey - Bolu and Çorum Provinces (Çobanoglu and Akdemir 2004), Trabzon Province (John and Breuss 2004); other lichens are rather well-known and common in the country (e.g. Yazici et al. 2007; Yazici et al. 2008; Kinalioğlu 2009). On primary squamules and inside the cup of podetium of $C$. pyxidata, a well developed thallus of Vulpicida pinastri (Scop.) J.-E. Mattsson \& M.J. Lai was observed. This lichen is typically characterized by its corticolous/lignicolous habitat; it also occurs occasionally on siliceous rocks (e.g. Nimis 1993). It is an interesting fact that Vulpicida pinastri could also be lichenicolous.

Cladonia acuminata (Ach.) Norll. (Fig. 2A)

Morphological description. Primary squamules persistent, numerous, small to medium-sized, up to $7 \mathrm{~mm}$ long, rather thin, usually ascending and sinuate, crenate to finely divided, grayish-green above and white below, esorediate; podetia up to $2.5 \mathrm{~cm}$ tall and $1-2 \mathrm{~mm}$ in diameter, cylindrical and slender, cupless and blunt, simple or somewhat branched in upper part; podetia partly verruculose-corticate, largely decorticate and with sparse coarse granular soredia in upper part, throughout covered by small and sparsely distributed squamules; apothecia small, brownish.

Chemistry. The specimen represents the chemotype with atranorin and norstictic acid as major substances, a trace amount of connorstictic acid was also detected. Spot test: $\mathrm{K}+$ yellow, $\mathrm{P}+$ orange, $\mathrm{C}-, \mathrm{KC}-, \mathrm{UV}-$. Chemically variable species (Stenroos and Ahti 1990; Ahti 2000), often including psoromic acid (e.g. Huovinen et al. 1989; Zhurbenko and Ahti 2005).

Ecology. The specimen was found on soil rich in humus, in an open situation in the vicinity of a coniferous forest.

Notes. Cladonia acuminata belongs to the section Helopodium and is related to C. cariosa and C. symphycarpa (Stenroos et al. 2002). All of these species may produce atranorin and norstictic acid (e.g. Huovinen et al. 1989; Smith et al. 2009). However, the podetia of C. cariosa are rather short and squat, not sorediate, distinctly fissured and crowned with usually large chocolatebrown apothecia. C. symphycarpa rarely forms short podetia and its thallus consists of large, well developed and densely growing basal squamules. Recently $C$. cariosa and C. symphycarpa have been reported from Turkey (Çobanoglu and Akdemir 2004; John and Breuss 2004; Yazici et al. 2007) and the new locality of the second species is added here.

World distribution. Mainly a circumpolar-boreal species, it appears in montane to alpine belts in the Northern Hemisphere. Also reported from South America (e.g. Stenroos and Ahti 1990; Burgaz and Raggio 2007). Rarely reported from Asia (Ahti 1976; Kurokawa 2003; Wagner and Spribille 2005; Zhurbenko and Ahti 2005); it seems that the species is rare, but rather widespread in the boreal zone and the mountainous regions of the continent.

Specimen examined. TURKEY, Ardahan Province: [locality 1] center of Posof District, Control Tower Forests, 41 ${ }^{\circ} 29^{\prime} 44.17^{\prime} \mathrm{N} / 42^{\circ} 44^{\prime} 03.88^{\prime}$ 'E, $1430 \mathrm{~m}, 07.12 .2008$, leg. K. Yazici (KTUB 2024).

Cladonia monomorpha Aptroot, Sipman \& van Herk (Fig. 2B)

Morphological description. Primary squamules persistent, relatively large and thick, up to $5 \mathrm{~mm}$ long, densely growing but not coalescent, usually ascending, olive to brown above and white below, brownish at the base; podetia up to $1 \mathrm{~cm}$ tall with \pm regular cups, scyphi c. $3-5 \mathrm{~mm}$ wide, gradually flaring, inside covered with distinctly cor- 
ticate bullate plates, outer surface mostly corticate-areolate and also with bullate plates, plates grade into squamules; apothecia small and brown.

Chemistry. It contains fumarprotocetraric acid (spot test: $\mathrm{K}-, \mathrm{P}+$ red, $\mathrm{C}-, \mathrm{KC}-, \mathrm{UV}-$ ). According to Aptroot et al. (2001), unidentified accesory substances may occasionally be detected.

Ecology. The specimens were found on humous soil among mosses in a well-lit and open situation, a forest dominated by Pinus sylvestris.

Notes. The species has recently been distinguished and described from Europe (Aptroot et al. 2001) and it is related to C. pocillum (Ach.) Grognot and C. pyxidata (L.) Hoffm. The specimens from Turkey quoted here correspond exactly with the characteristics of the taxon provided by Aptroot et al. (2001). For detailed descriptions of $C$. monomorpha and its comparison with similar taxa see Aptroot et al. (2001), Kowalewska and Kukwa (2004), and Kowalewska et al. (2008). It is worth mentioning that the species is regarded by some authors as a taxon of uncertain status (e.g. Santesson et al. 2004; Smith et al. 2009) or even as a synonym of C. pyxidata (e.g. Nimis 2003). On the other hand, other lichenologists maintain that the species is very distinct and worth recognition at the specific level (e.g. Kowalewska et al. 2008; Diederich et al. 2009). It seems the status of $C$. monomorpha needs more attention and perhaps a resolution based on molecular studies.

World distribution. The species is known from Europe (Aptroot et al. 2001), North America (Greenland and the U.S.A.) and Asia (Mongolia) (Kowalewska et al. 2008).

Specimens examined. TURKEY, Ardahan Province: [locality 4] Bağdaşan village forests, $41^{\circ} 03^{\prime} 08^{\prime \prime} \mathrm{N} /$ 42 ${ }^{\circ} 2$ '21'”E, $2010 \mathrm{~m}$, among mosses, 12.04.2009, leg. K. Yazici (KTUB 2025); [locality 5] Göle District, Yeniköy,

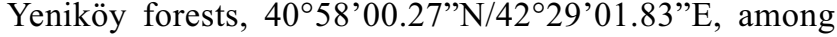
mosses, together with Cladonia subulata, $1960 \mathrm{~m}$, 27.07.2008, leg. K. Yazici (KTUB 2033).

Cladonia coniocraea (Flörke) Spreng. - TURKEY, Ardahan Province: [locality 4] Bağdaşan village forests, $41^{\circ} 03^{\prime} 08^{\prime} \mathrm{N} / 42^{\circ} 24^{\prime} 21^{\prime \prime} \mathrm{E}, 2010 \mathrm{~m}$, on humous soil among mosses, 12.04.2009, leg. K. Yazici (KTUB 2026).

Cladonia fimbriata (L.) Fr. - TURKEY, Ardahan Province: [locality 5] Göle District, Yeniköy, Yeniköy forests, $40^{\circ} 58^{\prime} 00.27^{\prime \prime} \mathrm{N} / 42^{\circ} 29^{\prime} 01.83^{\prime \prime} \mathrm{E}, 1960 \mathrm{~m}$, on humous soil among mosses, 27.07.2008, leg. K. Yazici (KTUB 2032).

Cladonia foliacea (Huds.) Willd. - TURKEY, Ardahan Province: [locality 3] Hanak District, Altaş village,

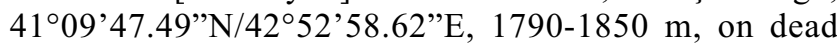
mosses, 28.07.2009, leg. K. Yazici (KTUB 2027).

Cladonia furcata (Huds.) Schrad. subsp. furcata TURKEY, Ardahan Province: [locality 1] Posof District, center (Control Tower Forests), 41 ${ }^{\circ} 29^{\prime} 44.17^{\prime \prime} \mathrm{N} / 42^{\circ}$ 44'03.88'E, $1430 \mathrm{~m}$, on soil, 07.12.2008, leg. K. Yazici (KTUB 2031).

Cladonia pyxidata (L.) Hoffm. - TURKEY, Ardahan Province: [locality 4] Bağdaşan village forests, 41 ${ }^{\circ} 03^{\prime} 08^{\prime}$ 'N $/ 42^{\circ} 24^{\prime} 21^{\prime \prime} \mathrm{E}, 2010 \mathrm{~m}$, on mosses, 12.04.2009, leg. K. Yazici (KTUB 2028) - primary squamules and the interior of the podetial cup are partly occupied by the thallus of Vulpicida pinastri (Fig. 2C).

Cladonia pocillum (Ach.) Grognot - TURKEY, Ardahan Province: [locality 2] Çamlıbel, $41^{\circ} 12^{\prime} 15.39$ "N/42。
33'08.14" E, on mosses, 2302 m, 31.07.2009, leg. K. Yazici (KTUB 2034).

Cladonia subulata (L.) Weber ex F.H. Wigg. TURKEY, Ardahan Province: [locality 5] Göle District, Yeniköy, Yeniköy forests, 4058'00.27’N/42²9'01.83'E, on mosses, $1960 \mathrm{~m}, 27.07 .2008$, leg. K. Yazici (KTUB 2030).

Cladonia symphycarpa (Flörke) Fr. - TURKEY, Ardahan Province: [locality 6] Göle, Göle-Ardahan Mainroad side, about $20 \mathrm{~km}$ from Ardahan, 40 54'57.54”N/ 42 35'48.11' E, on mosses, c. 1980-2000 m, 26.07.2009, leg. K. Yazici (KTUB 2029).

\section{Nomenclatural note:}

The epithet "symphycarpa" instead of "symphycarpia" is used because the original spelling published by Flörke turned out to be correct (Ahti pers. comm., see also McCune et al. 2009).

\section{ACKNOWLEDGEMENTS}

This study is supported by TUBITAK project (code 107T035). The authors are very grateful to Dr hab. Lucyna Śliwa (Kraków) for her precious comments and constructive discussion and the anonymous reviewer for several valuable improvements on an earlier draft of this paper.

\section{LITERATURE CITED}

AHTI T. 1976. The lichen genus Cladonia in Mongolia. Jour. Jap. Bot. 51: 365-373.

AHTI T. 2000. Cladoniaceae - Flora Neotropica, 78. Organization for Flora Neotropica and New York Botanical Garden, Bronx, pp. 362.

AKMAN Y. 1999. Climate and Bioclimate (The Methods of Bioclimate and Climate Types of Turkey). 1st Edn., Kariyer Matbaacılık Ltd., Şti, Ankara, pp. 350.

APTROOT A., SIPMAN H.J.M., VAN HERK C.M. 2001. Cladonia monomorpha, a neglected cup lichen from Europe. Lichenologist 33(4): 271-283.

BURGAZ A.R., RAGGIO J. 2007. The Cladoniaceae of Navarino Island (Prov. Antártica Chilena, Chile). Mycotaxon 99: 103-116 .

ÇOBANOGLU G., AKDEMIR B. 2004. Contribution to the lichen diversity of Nature Parks in Bolu and Çorum, Anatolia, Turkey. Herzogia 17: 129-136.

DAVIS P.H. 1965. Flora of Turkey and the East Aegean Islands. Vol. 1. Edinburgh University Press, Edinburgh, pp. 78.

DIEDERICH P., ERTZ D., STAPPER N., SÉRUSIAUX E., VAN DEN BROECK D., VAN DEN BOOM P., RIES C. 2009. Lichens of Belgium, Luxembourg and northern France. http:// www.lichenology.info, date of exploration: 15.02.2010.

HUOVINEN K., AHTI T., STENROOS S. 1989. The composition and contents of aromatic lichen substances in Cladonia section Helopodium and subsection Foliosae. Ann. Bot. Fenn. 26: 297-306

JOHN V., BREUSS O. 2004. Flechten der östlichen Schwarzmeer-Region in der Türkei. Herzogia 17: 137-156.

KINALIOĞLU K. 2009. Lichens from the Amasya, Çorum, and Tokat regions of Turkey. Mycotaxon 109: 181-184.

KOWALEWSKA A., KUKWA M. 2004. New records of Cladonia monomorpha (Cladoniaceae, lichenized Ascomycota) from Europe in Europe. Herzogia 17: 103-105.

KOWALEWSKA A., KUKWA M., OSTROWSKA I., JABŁOŃSKA A., OSET M., SZOK J. 2008. The lichens of the 
Cladonia pyxidata-chlorophaea group and allied species in Poland. Herzogia 21: 61-78.

KUROKAWA S. 2003. Checklist of Japanese Lichens. National Science Museum, Tokyo, pp. 128.

McCUNE, B., HOLT E.A., NEITLICH P.N., AHTI T., ROSENTRETER R. 2009. Macrolichen diversity in Noatak National Preserve, Alaska. North American Fungi 4 (4):1-22.

NIMIS P.L. 1993. The Lichens of Italy. An annotated catalogue. Museo Regionale di Scienze Naturali, Monografie XII, Torino, pp. 897.

NIMIS P.L. 2003. Checklist of the lichens of Italy. 3.0. http:// dbiodbs.univ.trieste.it, date of exploration: 15.02.2010.

ORANGE A., JAMES P.W., WHITE F.J. 2001. Microchemical methods for the identification of lichens. British Lichen Society, London, pp. 101.

SANTESSON R., MOBERG R., NORDIN A., TØNSBERG T., VITIKAINEN O. 2004. Lichen-forming and Lichenicolous Fungi of Fennoscandia. Museum of Evolution, Uppsala University, Uppsala, pp. 359.

SMITH C.W., APTROOT A., COPPINS B.J., FLETCHER A., GILBERT O.L., JAMES P.A., WOLSELEY P.A. 2009. The lichens of Great Britain and Ireland. British Lichen Society, London, pp. 1046.
STENROOS S., AHTI T. 1990. The lichen family Cladoniaceae in Tierra del Fuego: problematic or otherwise noteworthy taxa. Ann. Bot. Fenn. 27: 317-327.

STENROOS S., HYVÖNEN J., MYLLYS L., THELL A., AHTI T. 2002. Phylogeny of the genus Cladonia s.lat. (Cladoniaceae, Ascomycetes) inferred from molecular, morphological, and chemical data. Cladistics 18: 237-278.

WAGNER V., SPRIBILLE T. 2005. Preliminary checklist of the lichens of Kazakhstan. http://www.geobotanik.uni-goettingen.de/spribille, date of exploration: 15.02.2010.

YAZICI K., APTROOT A., ASLAN A. 2007. Lichen biota of Zonguldak, Turkey. Mycotaxon 102: 257-260.

YAZICI K., APTROOT A., ETAYO J., ASLAN A., GUTTOVÁ A. 2008. Lichens from the Batman, Mardin, Osmaniye, and Sivas regions of Turkey. Mycotaxon 103: 141-144.

YAZICI K., APTROOT A., ASLAN A. 2010a. Three lichenized fungi new to Turkey and the Middle East. Mycotaxon 111: 127-130.

YAZICI K., ELIX J.A., ASLAN A. 2010b. Some parmelioid lichens new to Turkey and Asia. Mycotaxon 111: 489-494.

ZHURBENKO M., AHTI T. 2005. Contribution to the study of the lichen genera Cladina and Cladonia in the Russian Arctic, mainly from Taimyr Peninsula and Severnaya Zemlya. Nova Hedwigia 81(1-2): 79-95. 